\title{
Potent Phosphodiesterase Inhibition and Nitric Oxide Release Stimulation of Anti-Impotence Thai Medicinal Plants from “MANOSROI III" Database
}

\author{
Aranya Manosroi, ${ }^{1,2,3}$ Theeraphong Tangjai, ${ }^{3,4}$ \\ Charinya Chankhampan, ${ }^{1,2,3}$ Worapaka Manosroi, ${ }^{5}$ Yaravee Najarut, ${ }^{1}$ \\ Worapong Kitdamrongtham, ${ }^{1,2}$ and Jiradej Manosroi ${ }^{1,2,3}$ \\ ${ }^{1}$ Manosé Health and Beauty Research Center, Chiang Mai 50200, Thailand \\ ${ }^{2}$ Faculty of Science and Technology, North-Chiang Mai University, Chiang Mai 50230, Thailand \\ ${ }^{3}$ Research Administration Center, Chiang Mai University, Chiang Mai 50200, Thailand \\ ${ }^{4}$ Faculty of Pharmacy, Payap University, Chiang Mai 50000, Thailand \\ ${ }^{5}$ Faculty of Medicine, Chiang Mai University, Chiang Mai 50200, Thailand \\ Correspondence should be addressed to Jiradej Manosroi; jiradej.manosroi8@gmail.com
}

Received 5 April 2017; Revised 5 June 2017; Accepted 21 June 2017; Published 25 July 2017

Academic Editor: Hajime Nakae

Copyright ( 2017 Aranya Manosroi et al. This is an open access article distributed under the Creative Commons Attribution License, which permits unrestricted use, distribution, and reproduction in any medium, provided the original work is properly cited.

\begin{abstract}
Seven plants in the top rank were selected from the "MANOSROI III" database using the two Thai keywords which meant impotence and sexual tonic. Boesenbergia rotunda (L.) Mansf. extract [EDP1-001(1)] gave the highest PDE inhibition activity of 4.36-fold sildenafil, a standard anti-impotence drug. Plumbago indica Linn. extract [EDP2-001(1)] exhibited the highest NO release stimulation activity of $666.85 \%$ which was 1.50 -fold acetylcholine, a standard drug. Most selected plant extracts were nontoxic to EA.hy926 cells at $1.0 \mathrm{mg} / \mathrm{mL}$. EDP1-001(1) exhibited the $\mathrm{LD}_{50}$ value of acute oral toxicity in male ICR mice of over 5,000 mg/kg body weight. EDP1-001(1) also indicated the improvement of sexual behaviors in the paroxetine-induced sexual dysfunction male mice with the evaluation of number of courtships (NC), mount frequency (MF), intromission frequency (IF), and ejaculatory frequency $(\mathrm{EF})$ at $87.67 \pm 6.17,121.00 \pm 23.50,36.00 \pm 3.21$, and $13.67 \pm 2.96$ which were 2.63-, 1.27-, 0.53-, and 0.62-fold sildenafil-treated mice at day 14 of the treatments, respectively. The present study has not only confirmed the traditional use of Thai plants for the treatment of ED but also indicated the potential and application of the "MANOSROI III" database for Thai plant selection to be developed as ED food supplements.
\end{abstract}

\section{Introduction}

Erectile dysfunction (ED) or impotence is a sexual disorder of men who fail to accomplish or maintain an adequate erection of penis to allow the pleasing of sexual intercourse. It is regarded as a major health problem of the ageing population and can cause considerable distress, unhappiness, and relationship problems [1]. Phosphodiesterases (PDEs) are classes of enzymes that are capable of cleaving the phosphodiester both in cyclic adenosine monophosphate (cAMP) and in cyclic guanosine monophosphate (cGMP), which are the important intracellular messengers to stimulate the penile smooth muscle relaxation and generate the penile erection. Sildenafil, the first effective oral drug, belongs to the group called selective phosphodiesterase type 5 (PDE-5) inhibitors. This drug preserves the cAMP and cGMP levels by inhibiting the action of phosphodiesterase enzymes, thereby enhancing and prolonging the penile erection. However, it may cause moderate to serious side effects, such as headache, facial flushing, dyspepsia, visual disturbance, heart attack, or stroke and even death [2-4]. Nitric oxide (NO) released from the autonomic nerve terminals supplying the penis and the endothelium of penile vascular structures is a primary neurotransmitter that plays a crucial role in penile erection. It activates the soluble guanylyl cyclase enzyme to produce cGMP, resulting in the stimulation of penile smooth muscle 
relaxation and erection of the penis. NO signaling pathway is now understood to be a novel and promising therapy for ED [4-6].

The Thai medicinal plant recipe database "MANOSROI III" has been developed since 1993 by Professor Dr. Jiradej Manosroi. The recipes have been collected, interpreted, and recorded in this database. This database contains the Thai medicinal plant recipes for pharmaceuticals, cosmetics, and food supplements from all regions of Thailand of over 89,000 recipes with more than 8,300 medicinal plants, as the folklore wisdom treatments of several diseases and symptoms including ED. Many research outcomes have been produced from this database. Several Thai medicinal plant recipes as well as Thai medicinal plants contained in the recipes have long been traditionally used for enhancing sexual performance. In this present study, the two Thai keywords including "Sueam Sa Mat Tha Phap Thang Phet" and "Bam Rung Kam Lang Thang Phet" which meant impotence and sexual energizer, respectively, have been used to search for the target ED plants from this database. The PDE inhibition and NO release stimulation as well as the phytochemicals and the in vivo acute toxicity of the extracts from the selected plants were investigated. In addition, sexual behavior stimulatory effects of the selected extract were evaluated on paroxetine-induced sexual dysfunction male mice. The results from this study can confirm the traditional use for ED which will be beneficial for the further development of the selected plant as a novel drug for ED treatment.

\section{Materials and Methods}

2.1. Materials and Chemicals. The PDE activity assay kit containing the PDE enzyme from bovine brain, $5^{\prime}$-nucleotidase, $3^{\prime}, 5^{\prime}$-cGMP substrate, PDE assay buffer, and green assay reagent were purchased from Abcam (Cambridge, MA, USA). Sildenafil citrate, acetylcholine chloride, $\mathrm{N}_{\omega}$-nitro-Larginine methyl ester hydrochloride (L-NAME), sulforhodamine B (SRB), Griess reagent, $17 \alpha$-ethinylestradiol, and progesterone were obtained from Sigma-Aldrich (St. Louis, MO, USA). Dulbecco's Modified Eagle Medium (DMEM) and fetal bovine serum (FBS) were from Gibco ${ }^{\circledR}$, Life Technologies Corporation (NY, USA). DMEM-no phenol red was from HyClone ${ }^{\mathrm{TM}}$, GE Healthcare Life Sciences (UT, USA). Paroxetine hydrochloride was obtained from GlaxoSmithKline (Bangkok, Thailand). All other chemicals and reagents were of analytical grade.

2.2. Selection of Plants from the Thai Medicinal Plant Recipe Database "MANOSROI III". The aphrodisiac medicinal plants were searched from the Thai medicinal plant recipe database "MANOSROI III" using the two Thai keywords of "Sueam Sa Mat Tha Phap Thang Phet" and "Bam Rung Kam Lang Thang Phet" which meant impotence and sexual tonic, respectively. The searched plants were coded with EDP1 and EDP2 for "Sueam Sa Mat Tha Phap Thang Phet" and "Bam Rung Kam Lang Thang Phet," respectively. To select the plants, the plants were ranked by frequencies of appearing in the recipes and coded with 001, 002, 003, and so forth, respectively. The plants which were in the top three from each of the searched keywords with the total of 6 plants were selected for this study.

2.3. Plant Materials. All selected plants were collected from Chiang Mai Province in Thailand during June to December in 2014. The voucher specimens of the collected plants were kept at MANOSÉ Health and Beauty Research Center (http://www.manose.co), Chiang Mai, Thailand. The plant materials were washed, cut into small pieces, dried at $50^{\circ} \mathrm{C}$, and then ground to powder.

2.4. Preparation of the Plant Extracts. The plant powder was weighed at $20 \mathrm{~g}$. The extracts were prepared from each plant according to the methods indicated in the recipes (containing the selected plants) (methods A to D). The obtained extracts were calculated for yields, kept in glass bottles, and stored at $4 \pm 2^{\circ} \mathrm{C}$ until use. The details of each preparation method indicated in the recipes were as follows.

Method A: The Recipes Were Orally Administered Together with Honey or Molded as Traditional Pills. Briefly, the plant powder was mixed with $300 \mathrm{~mL}$ of distilled water. The mixtures were stirred for $60 \mathrm{~min}$ and centrifuged at $9,000 \mathrm{~g}$ in room temperature $\left(27 \pm 2^{\circ} \mathrm{C}\right)$ for $5 \mathrm{~min}$. The supernatants were filtered through Whatman ${ }^{\mathrm{TM}}$ no. 1 filter paper (GE Healthcare UK Limited, Buckinghamshire, UK). The filtrates were concentrated by a rotary evaporator (BÜCHI Labortechnik AG, Flawil, Switzerland) at $50 \pm 2^{\circ} \mathrm{C}$ and lyophilized by a freeze dryer (Christ Alpha 1-2 LD, Martin Christ Gefriertrocknungsanlagen $\mathrm{GmbH}$, Osterode am Harz, Germany).

Method B: The Recipes Were Boiled with Water. Briefly, the plant powder was mixed with $300 \mathrm{~mL}$ of distilled water and boiled for $15 \mathrm{~min}$. After cooling, the mixtures were centrifuged at $9,000 \mathrm{~g}$ in room temperature $\left(27 \pm 2^{\circ} \mathrm{C}\right)$ for $5 \mathrm{~min}$. The supernatants were filtered through Whatman no. 1 filter paper (GE Healthcare UK Limited, Buckinghamshire, UK). The filtrates were concentrated by a rotary evaporator (BÜCHI Labortechnik AG, Flawil, Switzerland) at $50 \pm 2^{\circ} \mathrm{C}$ and lyophilized by a freeze dryer (Christ Alpha 1-2 LD, Martin Christ Gefriertrocknungsanlagen $\mathrm{GmbH}$, Osterode am Harz, Germany).

Method C: The Recipes Were Used as an Infusion. Briefly, the plant powder was mixed with $300 \mathrm{~mL}$ of hot distilled water and stirred for $15 \mathrm{~min}$. After cooling, the mixtures were centrifuged at $9,000 \mathrm{~g}$ in room temperature $\left(27 \pm 2^{\circ} \mathrm{C}\right)$ for $5 \mathrm{~min}$. The supernatants were filtered through Whatman no. 1 filter paper (GE Healthcare UK Limited, Buckinghamshire, UK). The filtrates were concentrated by a rotary evaporator (BÜCHI Labortechnik AG, Flawil, Switzerland) at $50 \pm 2^{\circ} \mathrm{C}$ and lyophilized by a freeze dryer (Christ Alpha 1-2 LD, Martin Christ Gefriertrocknungsanlagen $\mathrm{GmbH}$, Osterode am Harz, Germany).

Method D: The Recipes Were Orally Administered as a Herbal Liquor. Briefly, the plant powder was mixed with $300 \mathrm{~mL}$ of $40 \%$ ethanol in distilled water and stirred for $60 \mathrm{~min}$. The mixtures were centrifuged at $9,000 \mathrm{~g}$ in room temperature 
$\left(27 \pm 2^{\circ} \mathrm{C}\right)$ for $5 \mathrm{~min}$. The supernatants were filtered through the Whatman no. 1 filter paper (GE Healthcare UK Limited, Buckinghamshire, UK). The filtrates were concentrated by a rotary evaporator (BÜCHI Labortechnik AG, Flawil, Switzerland) at $50 \pm 2^{\circ} \mathrm{C}$ and lyophilized by a freeze dryer (Christ Alpha 1-2 LD, Martin Christ Gefriertrocknungsanlagen $\mathrm{GmbH}$, Osterode am Harz, Germany).

2.5. PDEs Activity Inhibition Assay. The PDEs activity inhibition of the selected plant extracts was examined by the modified method [7]. Briefly, $10 \mu \mathrm{L}$ of the plant extract in distilled water at $1.0 \mathrm{mg} / \mathrm{mL}$ was mixed with $20 \mu \mathrm{L}$ of $0.5 \mathrm{mM}$ $3^{\prime}, 5^{\prime}$-cGMP substrate solution, $5 \mu \mathrm{L}$ of PDE assay buffer, $10 \mu \mathrm{L}$ of $5 \mathrm{kU} / \mu \mathrm{L} 5^{\prime}$-nucleotidase solution, and $5 \mu \mathrm{L}$ of $4 \mathrm{U} / \mathrm{mL}$ PDE solution in each well of the 96-well half-area microplates (Greiner Bio-One GmbH, Frickenhausen, Germany). The mixtures were incubated at $37 \pm 1^{\circ} \mathrm{C}$ for $60 \mathrm{~min}$. The reaction was stopped by adding $100 \mu \mathrm{L}$ of the green assay reagent and the mixtures were left to settle at room temperature $\left(27 \pm 2^{\circ} \mathrm{C}\right)$ for $20 \mathrm{~min}$. The absorbance of the mixtures was measured at $620 \mathrm{~nm}$ by a microplate reader (Bio-Rad Laboratories, California, USA). Since the PDEs activity assay was evaluated by measuring the phosphate amounts from the reaction, the amounts of the phosphate existing in the extracts were determined by using the control system of mixing $10 \mu \mathrm{L}$ of the extract solution with $40 \mu \mathrm{L}$ of distilled water in each well of the 96 -well half-area microplates. The mixtures were incubated at $37 \pm 1^{\circ} \mathrm{C}$ for $60 \mathrm{~min}$ and added with $100 \mu \mathrm{L}$ of the green assay reagent. After keeping at room temperature $\left(27 \pm 2^{\circ} \mathrm{C}\right)$ for $20 \mathrm{~min}$, the absorbance of the mixtures was measured at $620 \mathrm{~nm}$ by a microplate reader. The inhibition of PDE activity was calculated by the following equation:

\% inhibition of PDEs activity

$$
=\frac{\mathrm{AR}_{\text {water }}-\left(\mathrm{AR}_{\text {sample }}-\mathrm{AC}_{\text {sample }}\right)}{\mathrm{AR}_{\text {water }}} \times 100 \text {, }
$$

where $\mathrm{AR}_{\text {water }}$ and $\mathrm{AR}_{\text {sample }}$ were the absorbance at $620 \mathrm{~nm}$ of the mixtures obtained from the reaction of PDEs with distilled water and the plant extracts, respectively; $\mathrm{AC}_{\text {sample }}$ was the absorbance at $620 \mathrm{~nm}$ of the control system to determine the phosphate contents existing in the plant extracts. Each experiment was carried out in triplicate. To determine the concentrations of the extracts giving 50\% inhibition of the PDEs activity $\left(\mathrm{IC}_{50}\right)$, the concentration-activity curve was prepared by varying the concentrations of the extracts from 2 $\times 10^{-5}$ to $2 \times 10^{-1} \mathrm{mg} / \mathrm{mL}$. Distilled water and sildenafil citrate dissolved in distilled water were used instead of the extracts for the negative and positive controls, respectively. Folds of the PDEs activity inhibition in comparison to sildenafil citrate were calculated as the following equation:

Folds of the PDEs inhibition activity

$$
=\frac{\mathrm{IC}_{50} \text { of sildenafil citrate }}{\mathrm{IC}_{50} \text { of the samples }} .
$$

\subsection{Nitric Oxide Release Stimulation Assay}

2.6.1. Cell Culture. The human endothelial cells (EA.hy926) from American Type Culture Collection (ATCC) were cultured in the complete DMEM supplemented with $10 \%$ of FBS, $100 \mathrm{U} / \mathrm{mL}$ of penicillin, and $100 \mu \mathrm{g} / \mathrm{mL}$ of streptomycin. The cell culture was incubated at $37^{\circ} \mathrm{C}$ in a humidified $5 \% \mathrm{CO}_{2}$ incubator (Contherm Scientific Ltd., Petone, New Zealand). The culture medium was changed 2-3 times per week.

2.6.2. Cytotoxicity Assay. The cytotoxicity of the plant extracts on the Ea.hy926 cells was determined by the sulforhodamine B (SRB) assay. Briefly, the EA.hy926 cells $\left(1 \times 10^{5}\right.$ cells/well) in $180 \mu \mathrm{L}$ of the complete DMEM were added to each well of 96 -well microplate and incubated at $37^{\circ} \mathrm{C}$ for $24 \mathrm{~h}$ in a humidified $5 \% \mathrm{CO}_{2}$ incubator (Contherm Scientific Ltd., Petone, New Zealand). The medium was replaced with the DMEM (without the FBS) containing the plant extracts with the final concentration of $1.0 \mathrm{mg} / \mathrm{mL}$ and incubated for $1 \mathrm{~h}$. The medium was decanted out and the new complete DMEM was added and further incubated for $24 \mathrm{~h}$. The cells were fixed with $50 \mu \mathrm{L} /$ well of the $50 \%$ trichloroacetic acid solution and incubated at $4^{\circ} \mathrm{C}$ for $1 \mathrm{~h}$. The fixed cells were rinsed for five times with distilled water and dried at room temperature $(27 \pm$ $\left.2^{\circ} \mathrm{C}\right)$. After $24 \mathrm{~h}$, the cells were stained with $100 \mu \mathrm{L} /$ well of the $0.4 \%$ SRB solution and incubated at room temperature $(27 \pm$ $2^{\circ} \mathrm{C}$ ) for $30 \mathrm{~min}$. The excess SRB was removed. The cells were washed for 5-6 times with $1 \%$ acetic acid solution and dried at room temperature $\left(27 \pm 2^{\circ} \mathrm{C}\right)$ overnight. The staining SRB in the cells was dissolved by adding $100 \mu \mathrm{L}$ /well of the $10 \mathrm{mM}$ Tris-base solution with shaking for $30 \mathrm{~min}$. The absorbance was measured at $540 \mathrm{~nm}$ by a microplate reader (Bio-Rad Laboratories, California, USA) and the percentage of viable cells was calculated according to the following equation:

$$
\begin{aligned}
& \text { Percentages of viable cells } \\
& \qquad=\frac{A_{540} \text { of the samples }}{A_{540} \text { of the control }} \times 100,
\end{aligned}
$$

where $A_{540}$ was the absorbance at $540 \mathrm{~nm}$ and the control was the untreated cells.

2.6.3. Sample Treatment and Nitric Oxide Measurement. The nitrite concentration was measured using the Griess reaction as described by Green et al. [8]. The EA.hy926 cells $\left(1 \times 10^{5}\right.$ cells/well) were plated in each well of 96 -well microplate and incubated at $37^{\circ} \mathrm{C}$ for $24 \mathrm{~h}$ in a humidified $5 \% \mathrm{CO}_{2}$ incubator (Contherm Scientific Ltd., Petone, New Zealand). The cultured cells were treated with $100 \mu \mathrm{L}$ of the plant extract, acetylcholine chloride (a positive control), and L-NAME (a negative control) at $1.0 \mathrm{mg} / \mathrm{mL}$ in DMEM-no phenol red medium. After incubation at $37^{\circ} \mathrm{C}$ for $24 \mathrm{~h}, 100 \mu \mathrm{L}$ of the cultured cell supernatants was mixed with an equal volume of the Griess reagent and incubated at room temperature $\left(25^{\circ} \mathrm{C}\right)$ for $10 \mathrm{~min}$. The absorbance was measured at $540 \mathrm{~nm}$ using a microplate reader (Bio-Rad Laboratories, California, USA). The NO production of the EA.hy926 cells was calculated from the obtained absorbance by comparing with the standard concentration curve of sodium nitrite $\left(\mathrm{NaNO}_{2}\right)$ at 1-200 $\mu \mathrm{M}$ 
in the DMEM-no phenol red medium. Each experiment was carried out in triplicate. To determine the concentrations of the extracts giving $50 \%$ stimulation of the NO production activity $\left(\mathrm{SC}_{50}\right)$, the concentration-activity curve was prepared by varying the extract concentrations from $1 \times 10^{-4}$ to $1.0 \mathrm{mg} / \mathrm{mL}$. Folds of the NO release stimulation of the extract in comparing to acetylcholine chloride were calculated as the following equation:

Folds of the NO release stimulation activity

$$
=\frac{\mathrm{SC}_{50} \text { of acetylcholine chloride }}{\mathrm{SC}_{50} \text { of the samples }} \text {. }
$$

2.7. Phytochemical Determination. The plant extracts were analyzed for the presence of phytochemicals according to the standard procedures as previously described $[9,10]$. Briefly, alkaloids, anthraquinones, carotenoids, flavonoids, glycosides, saponins, tannins, and xanthones were detected by Dragendorff's reagent, ammonium hydroxide $\left(\mathrm{NH}_{4} \mathrm{OH}\right)$, sulfuric acid, Shinoda test, thin layer chromatography (TLC), Frothing test, ferric chloride $\left(\mathrm{FeCl}_{3}\right)$, and potassium hydroxide $(\mathrm{KOH})$, respectively.

\subsection{Acute Oral Toxicity}

2.8.1. Animals. Eight-week-old male ICR mice weighing between 25 and $40 \mathrm{~g}$ were obtained from the National Laboratory Animal Center, Nakhon Pathom, Thailand. The mice were maintained under the standard condition for laboratory animal housing controlled temperature at $24 \pm 1^{\circ} \mathrm{C}$ and humidity at $50 \pm 10 \%$ with the cycle of $12 \mathrm{~h}$ light and $12 \mathrm{~h}$ dark. The mice were fed with commercially available animal foods and allowed water ad libitum. All experiments were conducted in accordance with the directive 2010/63/EU and the guidelines for the care and use of laboratory animals of Chiang Mai University, Chiang Mai, Thailand. The date and number from the ethical committee of the Laboratory Animal Center, Chiang Mai University, for the in vivo experiment were 28/01/2016 and 002/2559[01/2559-01-28], respectively.

2.8.2. Acute Oral Toxicity Test. The acute oral toxicity of the selected plant extracts was performed according to the Organization Economic Co-operation and Development (OECD) guideline for testing of chemicals: Acute Oral Toxicity: Upand-Down Procedure (OECD guideline number 425) [11]. The male mice were weighed and randomly divided into two groups ( 5 mice per group). The animals were orally given using an oral feeding tube the vehicle (distilled water) as a control group in Group I and in Group II a single dose of the selected plant extract at 5,000 mg/kg body weight. Mortality and toxicity apparent signs or behavioral alterations of mice were observed daily for 14 days. The body weight changes of the mice were checked at day 14 . At the end of the experiment, each mouse was euthanized and the organs (heart, lung, liver, kidney, spleen, stomach, intestine, and testis) were collected for histopathology. The organs were isolated and preserved in $10 \%$ formalin in phosphate buffered saline (PBS) at $\mathrm{pH}$ 7.4. Each organ was weighed and the abnormal-weight organs were embedded in paraffin, cut into 6 and $12 \mu \mathrm{m}$ thickness, stained with hematoxylin and eosin, and examined under a light microscope (Olympus, Tokyo, Japan).

\subsection{Evaluation of Sexual Behavior Stimulatory Effects}

2.9.1. Animals. Healthy eight-week-old ICR male and female mice weighing $35-40 \mathrm{~g}$ and $30-35 \mathrm{~g}$, respectively, were obtained from the National Laboratory Animal Center, Nakhon Pathom, Thailand. The mice were maintained under the standard condition for laboratory animal housing controlled temperature at $24 \pm 1^{\circ} \mathrm{C}$ and humidity at $50 \pm 10 \%$ with the cycle of $12 \mathrm{~h}$ light and $12 \mathrm{~h}$ dark. The mice were fed with commercially available animal foods and allowed water ad libitum.

2.9.2. Induction of Estrous Period to the Female Mice. The female mice were induced to be in the estrous period by the procedure modified from the method of Aslam and Sial [12]. Briefly, the female mice were orally given $17 \alpha-$ ethinylestradiol at $2 \mathrm{mg} / \mathrm{kg}$ body weight and subcutaneously injected with progesterone at $20 \mathrm{mg} / \mathrm{kg}$ body weight, $48 \mathrm{~h}$ and $6 \mathrm{~h}$, respectively, before exposure to the male mice. The estrous period of the female mice was confirmed by vaginal smear examinations under microscopic observation [13].

2.9.3. Induction of Sexual Dysfunction or ED (Erectile Dysfunction) of the Male Mice. The male mice were induced to be in the state of sexual dysfunction by daily oral administration for 21 days of paroxetine suspension at $20 \mathrm{mg} / \mathrm{kg}$ body weight using a metal feeding tube [14]. The paroxetine suspension was prepared daily in Tween-80 suspended in normal saline solution. After 21 days, an estrous female mouse was introduced into each paroxetine-treated male mouse in a separate cage, and the sexual behaviors including numbers of courtship (NC), mount frequency (MF), intromission frequency (IF), and ejaculatory frequency (EF) were observed via a video record for $12 \mathrm{~h}$ between 6.00 p.m. and 6.00 a.m. The male mice which showed the minimum of $25 \%$ reduction in NC, MF, IF, and EF when compared with the normal male mice were considered as sexually dysfunctional and were used for the further study. The observing staffs were free from treatment information and have evaluated the male sexual behaviors according to the criteria of the previous studies $[15,16]$ as follows:

(i) Courtship: it is the amount of frequency it takes for a male to mount the female for the first time.

(ii) Mounting the female: the male normally mounts from the rear, sometimes posing his forelegs over the female's back, and rapidly makes.

(iii) Intromission vaginal penetration: this behavior starts with a mount, but suddenly the male makes a deep thrust forward and stops pelvic thrusting.

(iv) Ejaculation: this behavior starts with an intromission, but, after vaginal penetration (the deep forward thrust), the male remains on the female for $1-3 \mathrm{~s}$. 
2.9.4. Animal Grouping and Extract Administration. The paroxetine-induced sexual dysfunction male mice were randomly divided into three groups with 3 animals in each group. $300 \mu \mathrm{l}$ of distilled water, $0.02 \mathrm{~g} / \mathrm{kg}$ body weight of sildenafil (a standard PDE-5 inhibitor drug), and $1 \mathrm{~g} / \mathrm{kg}$ body weight of the plant extract were orally administered to each animal group using a metal oral feeding tube, once daily for 14 days. After 30 mins of administration, an estrous female mouse was introduced into each sample-treated male mouse in a separate cage and the sexual behaviors of the male mice were monitored at days 1,7 , and 14. The sexual behaviors including NC, MF, IF, and EF were observed via a video record for $12 \mathrm{~h}$ between 6.00 p.m. and 6.00 a.m.

2.10. Statistical Analysis. All assays were performed in triplicate of independent experiments. The data were presented as means \pm standard deviation (SD). Statistical evaluation was determined by the one-way analysis of variance (oneway ANOVA) with post hoc test of multiple comparisons. Statistical significance was considered at the $p$ values of less than 0.01 and 0.05 .

\section{Results and Discussion}

3.1. Selection of Plants from the Thai Medicinal Plant Recipe Database "MANOSROI III". Seven instead of six medicinal plants in the top three ranks searching by the two Thai keywords ("Sueam Sa Mat Tha Phap Thang Phet" and "Bam Rung Kam Lang Thang Phet") were obtained and used to prepare the extracts according to the details shown in Table 1 , since there were two medicinal plants that gave the same frequency in the selected aphrodisiac recipes.

3.2. Preparation of the Extracts. The extracts of the seven selected medicinal plants were prepared according to the traditional methods (methods A-D) from the recipes containing these plants. Fifteen extracts were obtained because some selected plants were from the recipes which indicated more than one traditional preparation method. The percentage yields and physical appearance of the extracts were demonstrated in Table 1 . Methods A-C used water as a solvent, while method D used ethanol as a solvent. Six out of 15 extracts were prepared by method A which was the traditional indication of most Thai medicinal plant recipes. The six extracts gave the percentage yields of $2.55-22.90 \%$, while the extract of Plumbago indica L. demonstrated the highest percentage yield of $22.90 \%$. However, the extract of $P$. indica prepared by method $\mathrm{C}$ gave the highest percentage yield of $26.60 \%$ compared to other extracts. This may be due to the use of hot water to prepare the extract in which the phytochemical compounds could be dissolved better than in cold water.

3.3. PDEs Activity Inhibition of the Selected Plant Extracts. The dose of 15 extracts at $200 \mu \mathrm{g} / \mathrm{mL}$ which was calculated from the traditional dose indicated in the recipes was tested for PDEs inhibition compared with sildenafil, a positive control PDE-5 inhibitor drug. The dose of sildenafil at $0.45 \mu \mathrm{g} / \mathrm{mL}$ was determined from the maximum plasma concentration of a single oral dose of tablet containing $100 \mathrm{mg}$ sildenafil in healthy male volunteers [17]. The $\mathrm{IC}_{50}$ values and PDEs inhibition percentages of the extracts and sildenafil were shown in Table 2. All extracts [EDP1-001(1), EDP1001(2), EDP1-002(2), EDP1-003, EDP2-001(1), EDP2-002(2), and EDP2-003(2)] exhibited the PDEs inhibition percentages in the range of $2.72-65.28 \%$ of $0.18-4.36$-fold sildenafil. Sildenafil provided quite low inhibitory activity to PDEs because the dose of sildenafil $(0.45 \mu \mathrm{g} / \mathrm{mL})$ used in the test was lower than the extracts $(200 \mu \mathrm{g} / \mathrm{mL})$. The $\mathrm{IC}_{50}$ value of sildenafil was higher than EDP1-001(1). Also, sildenafil is a selective inhibitor of phosphodiesterase (PDE) type 5, but the nonselective phosphodiesterases (PDEs) assay was performed in this study. So, the different potency of PDEs inhibition activity between EDP1-001(1) and the standard sildenafil may be due to the different inhibition mechanism on PDEs. The mechanism of sildenafil is the potential endogenous increases in cGMP by inhibiting its breakdown at the catalytic site [18]. Orallo et al. [19] showed that $( \pm)$ naringenin as a natural flavonoid characterized as an agent with clear vasorelaxant effects on rat aortic smooth muscle is probably mediated by an increase in systolic cAMP and cGMP concentrations. However, some plant extracts showed PDEs stimulation effect (with the minus PDEs stimulation value). This may be due to affinity to noncatalytic CGMP blinding sites on the PDEs [20]. The highest PDEs inhibition percentage was observed in EDP1-001(1) extract at $65.28 \pm 2.09 \%$ of 4.36 -fold sildenafil. This extract gave the $\mathrm{IC}_{50}$ value of PDEs inhibition activity at $0.0026 \pm 0.0025 \mathrm{mg} / \mathrm{mL}$ of 2.23 -fold sildenafil (the $\mathrm{IC}_{50}$ value of sildenafil was $0.0058 \pm 0.0032 \mathrm{mg} / \mathrm{mL}$ ). This extract was prepared by method A using aqueous cold extraction of Boesenbergia rotunda (L.) Mansf. rhizome (Table 1). As previously reported, the ethanolic extract of this plant at $0.1 \mathrm{mg} / \mathrm{mL}$ showed complete inhibitory effect (100\% inhibition) against PDEs [21]. This ethanolic extract at $50 \mu \mathrm{g} / \mathrm{mL}$ also exhibited the selective inhibition against PDE-5 activity of $40.86 \pm 3.94 \%$ [22]. In addition, this present study has also demonstrated high PDEs inhibition activity of EDP1002(2), EDP2-003(2), EDP1-003, and EDP0-001(2) which were extracts from Piper nigrum Linn., Piper interruptum Opiz, Diospyros rhodocalyx Kurz., and Plumbago indica Linn., respectively. Although sildenafil is a PDE5 inhibitor, the common side effects such as headache, flushing, dizziness, nasal congestion, and dyspepsia, which are a reflection of the vasodilatory effects on the capillary smooth muscle in other parts of the body, have been reported. So far, the inhibitory selectivity on PDE5 of the extract from B. rotunda has not been investigated. However, this extract was obtained from $B$. rotunda which is a Thai medicinal plant that has long been traditionally consumed. In addition, Saraithong et al. [23] have demonstrated that the ethanolic extract of $B$. rotunda was safe for consumption as in vivo studies of $B$. rotunda fed to rats showed no significant changes in body weight and all hematological and histopathological parameters used to evaluate the toxicity effect did not show any adverse changes. Thus, the extract from $B$. rotunda is safe for consumption. This result has indicated the enhancing sexual performance potential of the Thai medicinal plants searched from the Thai medicinal plant recipe database "MANOSROI III," which 







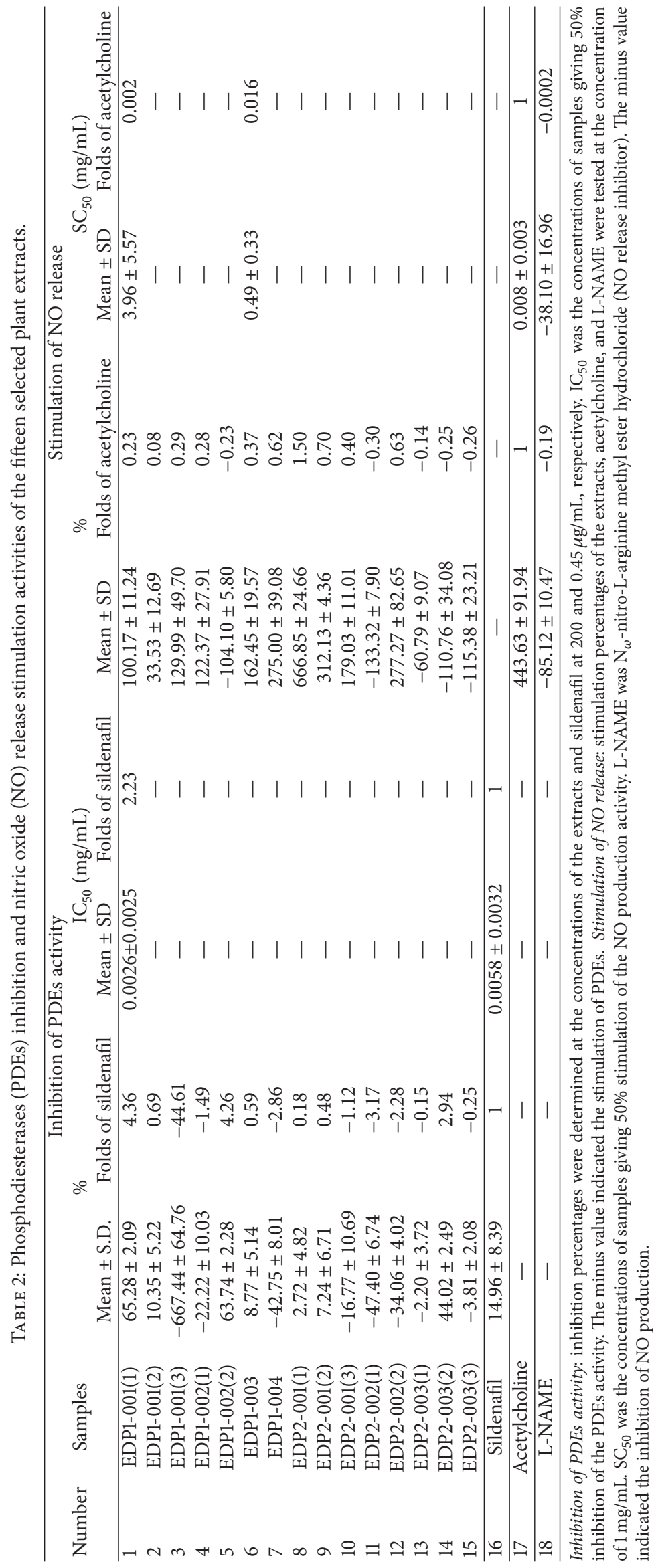




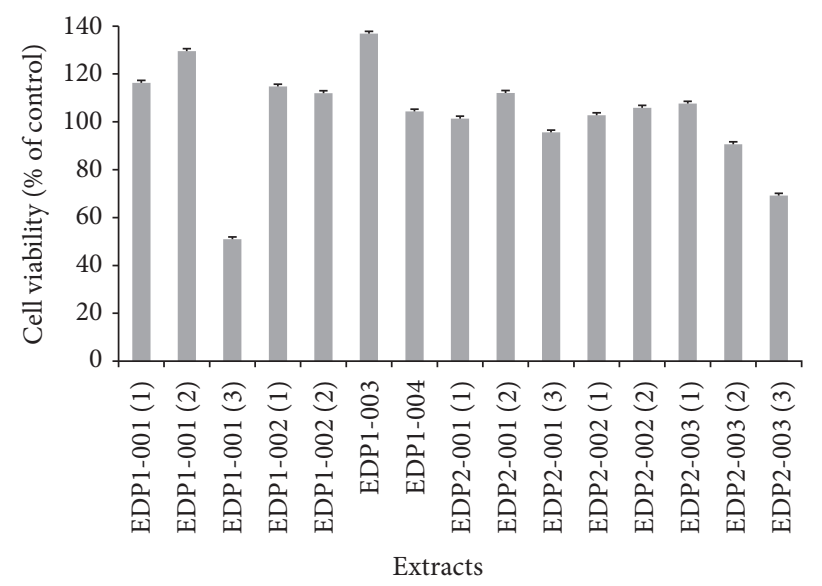

FIGURE 1: Cell viability of EA.hy926 treated with the 15 selected plant extracts at $1.0 \mathrm{mg} / \mathrm{mL}$ [\% cell viability $=\left(A_{540}\right.$ of the sample/ $A_{540}$ of the control) $\times 100$, where $A_{540}$ was the absorbance at $540 \mathrm{~nm}$ and the control was the untreated cells].

have long been traditionally used in humans. In fact, this long traditional use in humans is similar to the clinical trial step in the research and development of the modern drugs [6].

\subsection{NO Release Stimulation Activity of the Selected Plant} Extracts. The NO released from endothelial cells is a major endogenous vasodilator system for counterbalancing the vasoconstriction produced by the sympathetic nervous system and the rennin-angiotensin system [24]. In Figure 1, the cell viability percentages of EA.hy926 treated with all selected plant extracts, except EDP1-001(3) and EDP2-003(3) at $1.0 \mathrm{mg} / \mathrm{mL}$, were close or more than $100 \%$ of the control. Only EDP1-001(3) and EDP2-003(3) at $1.0 \mathrm{mg} / \mathrm{mL}$ exhibited cell viability of less than $70 \%$ of the control. Thus, the extract at $1.0 \mathrm{mg} / \mathrm{mL}$ was used for the NO release stimulation assay. In Table 2, ten out of 15 selected plant extracts including EDP1-001(1), EDP1-001(2), EDP1-001(3), EDP1-002(1), EDP1003, EDP1-004, EDP2-001(1), EDP2-001(2), EDP2-001(3), and EDP2-002(2) showed the NO release stimulation activity in the range of $33.53-666.85 \%$. EDP2-001(1) exhibited the highest NO release stimulation activity of $666.85 \pm 24.66 \%$ with 1.50 -fold the acetylcholine (a positive control, which gave the activity of $443.63 \pm 91.94 \%)$. However, EDP1-002(2), EDP2-002(1), EDP2-003(1), EDP2-003(2), and EDP2-003(3) extracts displayed the NO release inhibition the same as LNAME (a NO release inhibitor, a negative control), indicating the inhibition of NO production. The EDP1-001(1) and EDP1-003 extracts exhibited the $\mathrm{SC}_{50}$ values of $\mathrm{NO}$ release stimulation at $3.96 \pm 5.57$ and $0.49 \pm 0.33 \mathrm{mg} / \mathrm{mL}$ of 0.002 - and 0.016 -fold acetylcholine (the $\mathrm{SC}_{50}$ value of acetylcholine was $0.008 \pm 0.003 \mathrm{mg} / \mathrm{mL}$ ), respectively. EDP1001(1) and EDP1-003 extracts were prepared by method A from Boesenbergia rotunda (L.) Mansf. and Diospyros rhodocalyx Kurz., respectively. High quantity of flavonoids at $12,975.52 \pm 71.78 \mu \mathrm{g} / \mathrm{g}$ of the dry weight of the B. rotunda extract has been reported [25]. Both flavonoids and phenolic compounds have been found in the D. rhodocalyx extract [26]. The flavonoid and phenolic compounds have been previously reported to exhibit NO production stimulation in the EA.hy926 cells $[27,28]$. Wang et al. have presented
TABLE 3: Phytochemicals of the selected plant extracts.

\begin{tabular}{lcc}
\hline Phytochemical contents & \multicolumn{2}{c}{ Extracts } \\
\hline Alkaloids & EDP1-001(1) & EDP1-003 \\
Anthraquinones & - & + \\
Carotenoids & - & - \\
Flavonoids & - & - \\
Glycosides & +++ & - \\
Saponins & - & - \\
Tannins & +++ & - \\
Xanthones & - & - \\
\hline
\end{tabular}

+++: abundant presence, +: slight presence; —: absence.

that the flavonoids in Shxiao San extract augmented the NO output in the EA.hy926 cells [28]. The treatment of EA.hy926 cells with an alcohol-free red wine polyphenol extract showed an increase of the NO release [29]. Thus, the NO release stimulation of the EDP1-001(1) and EDP1-003 extracts might be from the flavonoid and phenolic contents.

3.5. Phytochemical Determination of the Selected Plant Extracts. The phytochemical contents in the selected plant extracts were presented in Table 3. High contents of flavonoids and saponins were found in EDP1-001(1), whereas alkaloids and xanthones (phenolic compounds) were observed in EDP1-003. Bioactive compounds from rhizome extracts of $B$. rotunda have been classified mainly into two major groups including flavanones (alpinetin, pinostrobin, and pinocembrin) and chalcones (boesenbergin, cardamonin, panduratin A, and 4-hydroxypanduratin A) [30]. These compounds have estrogenic or androgenic activities and show phosphodiesterase inhibition activity [31]. Some plants have demonstrated PDEI activity related to their saponin contents. Mimaki et al. [32] reported that Lilium regale and Lilium henryi have inhibitory effects on cAMP PDE. The main active substances presented in these plants are steroidal saponins. Kuroda et al. [33] showed that 




(a)

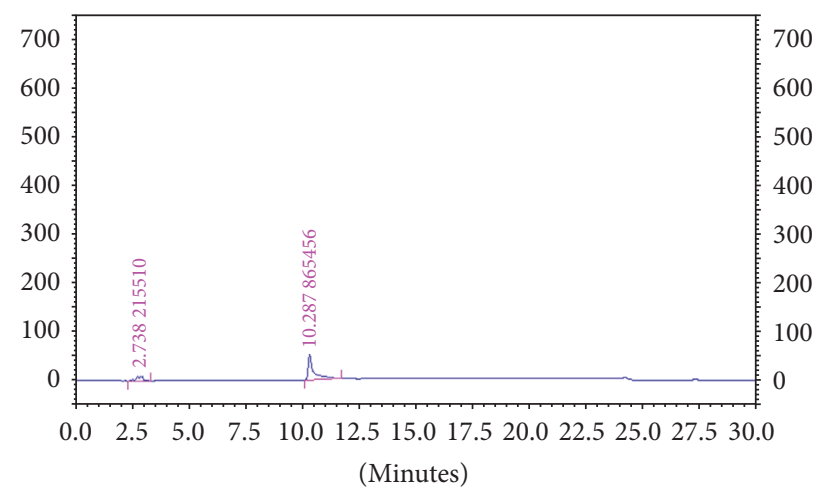

(b)

FIGURE 2: HPLC fingerprint of the EDP1-001(1) extract at $100 \mathrm{mg} / \mathrm{ml}$ (a) which exhibited the peak of flavone at the retention time of $10.345 \mathrm{~min}$ with the content of $58 \mu \mathrm{g} / \mathrm{mg}$ extract and HPLC fingerprint of the standard flavone at $1 \mathrm{mg} / \mathrm{ml}$ (b).

ethanol extract of Allium chinense has inhibitory activity on cAMP PDE, probably because of its saponin contents. These major bioactive compounds can be used as markers for phytochemical profile standardization. In this study, the HPLC fingerprint of the EDP1-001(1) extract using flavone as a marker was performed for quality control, with the flavone content of $58 \mu \mathrm{g} / \mathrm{mg}$ extract (Figure 2). Both flavonoids and phenolic compounds have been reported to be related to NO production stimulation [27-29], with the possible mechanism of increasing mRNA and protein expression of endothelial NO synthase (eNOS) in rats [34]. NO might be stimulated and released directly in the endothelial cells by activating the eNOS. Upadhyaya et al. have reported that flavonoids in Shixiao San increased the expression of eNOS [35]. In addition, an increase in the eNOS mRNA expression of the endothelial cells could be observed after being incubated with red wine polyphenol extract [29]. Thus, flavonoid contents in EDP1-001(1) appeared to be responsible for the $\mathrm{NO}$ release stimulation activity.

3.6. Acute Oral Toxicity. The EDP1-001(1) extract was further investigated for acute oral toxicity in male mice because it gave the highest activity of PDEs inhibition and high NO release stimulation activity with no cytotoxicity in the EA.hy926 cells (Table 4). Mortality, abnormal animal behaviors, toxic signs, and body weight changes compared to the control group of the male mice fed with a single dose of $5,000 \mathrm{mg} / \mathrm{kg}$ body weight were not observed. Hence, the median lethal dose $\left(\mathrm{LD}_{50}\right)$ of the EDP1-001(1) extract was more than $5,000 \mathrm{mg} / \mathrm{kg}$ body weight. In addition, no macroscopic change of the internal organs of all treated mice was indicated. Most internal organ weights of the extract-treated mice were not different from the control group, except the liver and intestine weights which increased significantly $(p<0.05)$ when compared with the control group. However, the histopathological examination of these two organs was not different from the control group. Therefore, the B. rotunda extract [EDP1-001(1)] was safe and appeared to have potential for the further development as a product.
3.7. Sexual Behavior Stimulatory Effects. Sildenafil at $0.02 \mathrm{~g} /$ $\mathrm{kg}$ body weight was calculated from the normal dose of sildenafil in human (100 mg/60 kg body weight) and adjusted by the dose conversion factor to mice [36]. The selected plant extract, EDP1-001(1), at $1 \mathrm{~g} / \mathrm{kg}$ body weight was obtained from the traditional indication in the recipe and also adjusted by the conversion factor from human to mice. The sexual behaviors including number of courtships (NC), mount frequency (MF), intromission frequency (IF), and ejaculatory frequency $(\mathrm{EF})$ of the paroxetine-induced sexual dysfunction male mice treated with the EDP1-001(1) extract compared to the control groups were shown in Tables 5 and 6 . The paroxetine-induced sexual dysfunction male mice that were orally given daily the EDP1-001(1) extract for 7 and 14 days exhibited sexual behavior improvement when compared with the mice treated with distilled water (the control group). At day 7 of the treatment, the NC and MF of the EDP1-001(1)treated mice were at $26.33 \pm 3.48$ and $17.00 \pm 12.34$ which were 1.44- and 17.00-fold the distilled water-treated mice (the control group), respectively. At day 14 of the treatment, the NC, MF, IF, and EF of the EDP1-001(1)-treated mice were at $87.67 \pm 6.17,121.00 \pm 23.50,36.00 \pm 3.21$, and $13.67 \pm 2.96$ which were 2.63-, 1.27-, 0.53-, and 0.62-fold the sildenafil-treated mice (the positive control group), respectively. The EDP1001(1) appeared to be a potential extract for the treatment of sexual dysfunction. However, the extract needed to be orally administered continuously for 7-14 days to obtain an improvement of sexual dysfunction symptoms, whereas sildenafil exhibited the improvement particularly at the initial treatment of day 1 . The higher sexual behavior stimulatory effects of the EDP1-001(1) extract at $1 \mathrm{~g} / \mathrm{kg}$ body weight than sildenafil at $0.02 \mathrm{~g} / \mathrm{kg}$ body weight might be due to the regulatory mechanism of male reproductive system that are not related only to the inhibition of PDEs activity, but also to the influence on androgens such as testosterone and the release of NO. This in vivo sexual dysfunction improvement of the EDP1-001(1) extract has confirmed the in vitro results of both the PDEs inhibition and the NO release stimulation with the $\mathrm{IC}_{50}$ value of $0.0026 \pm 0.0025 \mathrm{mg} / \mathrm{mL}(2.23$-fold sildenafil) and the $\mathrm{SC}_{50}$ value of $3.96 \pm 5.57 \mathrm{mg} / \mathrm{mL}(0.002-$ fold acetylcholine), respectively. 


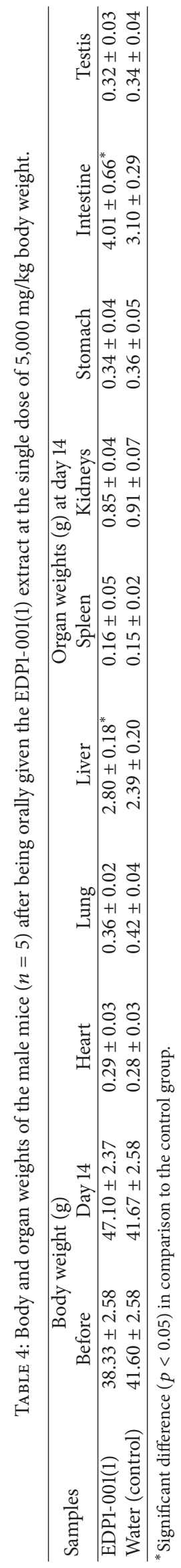




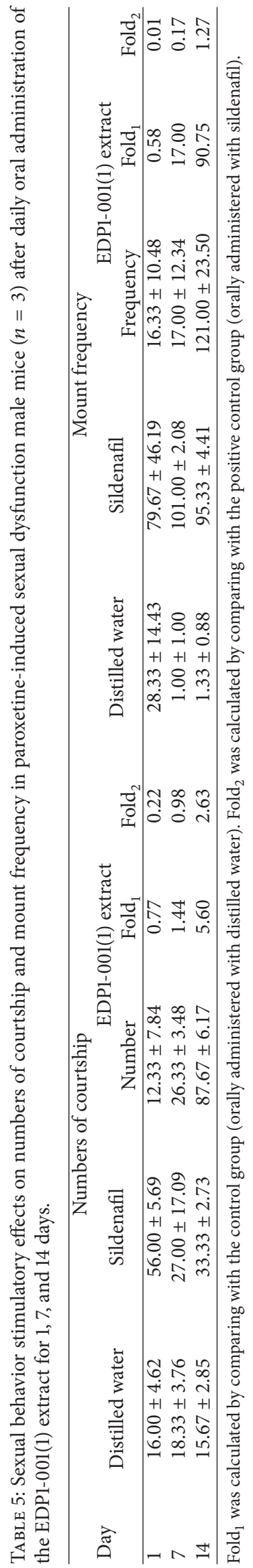




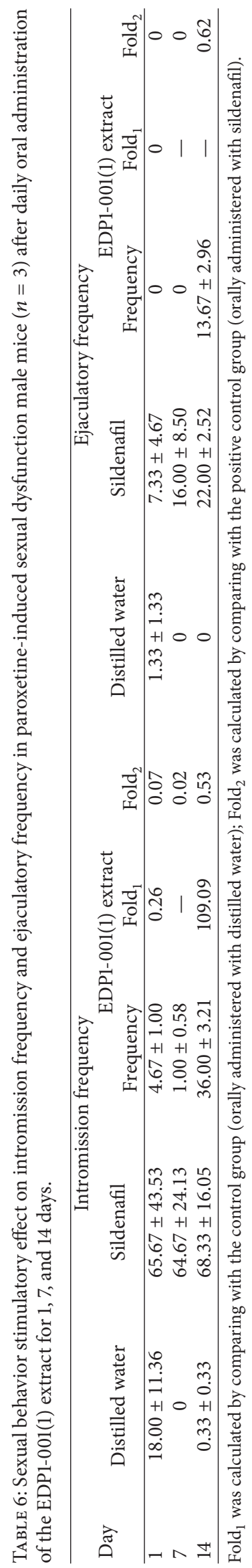




\section{Conclusions}

Several Thai medicinal plants appeared in the Thai medicinal plant recipe database "MANOSROI III" have long been traditionally used to treat various diseases and symptoms including ED. Seven aphrodisiac medicinal plants selected from the top three ranks searched from the "MANOSRO III" database by the 2 Thai keywords ("Sueam Sa Mat Tha Phap Thang Phet" and "Bam Rung Kam Lang Thang Phet") were prepared as 15 extracts. Only 7 extracts at $200 \mu \mathrm{g} / \mathrm{mL}$ exhibited the PDEs inhibition in the range of $2.72-65.28 \%$ which were $0.18-4.36$-fold sildenafil at $0.45 \mu \mathrm{g} / \mathrm{mL}$, while 10 out of 15 extracts at $1.0 \mathrm{mg} / \mathrm{mL}$ showed the NO release stimulation in the range of 33.53-666.85\% in the EA.hy926 cells which were $0.08-1.50$-fold acetylcholine at $1 \mathrm{mg} / \mathrm{mL}$. The EDP1-001(1) extract prepared from B. rotunda by method A gave the highest PDEs inhibition activity with the $\mathrm{IC}_{50}$ value of $0.0026 \pm 0.0025 \mathrm{mg} / \mathrm{mL}$ and the high $\mathrm{NO}$ release stimulation with the $\mathrm{SC}_{50}$ value of $3.96 \pm 5.57 \mathrm{mg} / \mathrm{mL}$. The EDP1-001(1) extract contained the high contents of flavonoids and saponins in which flavonoids have been reported to be related to NO production stimulation. The EDP1-001(1) was nontoxic to EA.hy926 cells at $1.0 \mathrm{mg} / \mathrm{mL}$. The EDP1001(1) extract showed no acute toxicity with no mortality, no abnormal animal behaviors, no toxic signs, and no body weight changes after oral administration in male ICR mice at a single dose of $5,000 \mathrm{mg} / \mathrm{kg}$ body weight. This extract also exhibited the sexual behavior improvement in the paroxetine-induced sexual dysfunction male mice after oral daily administration for 14 days when compared with the control group. At day 14 of the treatment, the NC, MF, IF, and EF of the EDP1-001(1)-treated mice were at $87.67 \pm 6.17$, $121.00 \pm 23.50,36.00 \pm 3.21$, and $13.67 \pm 2.96$ which were $2.63-$, $1.27-, 0.53-$, and 0.62 -fold the sildenafil-treated mice (positive control group), respectively. The results from this study have indicated not only the potential of the selected Thai plant extract for the further development as food supplements for ED but also the benefit of the Thai medicinal plant recipe database "MANOSROI III" as a convenient source for an efficient searching and ranking of the target plants for the treatment of various symptoms including ED.

\section{Conflicts of Interest}

The authors report no conflicts of interest.

\section{Acknowledgments}

This work was financially supported by the Agricultural Research Development Agency (Public Organization), Thailand, and the Manosé Health and Beauty Research Center, Chiang Mai, Thailand.

\section{References}

[1] R. Shamloul and H. Ghanem, "Erectile dysfunction," The Lancet, vol. 381, no. 9861, pp. 153-165, 2013.

[2] R. C. Rosen and J. B. Kostis, "Overview of phosphodiesterase 5 inhibition in erectile dysfunction," American Journal of Cardiology, vol. 92, no. 9, 2003.
[3] P. J. Kadowitz, G. F. Lasker, and J. H. Maley, "A review of the pathophysiology and novel treatments for erectile dysfunction," Advances in Pharmacological Sciences, vol. 2010, Article ID 730861, 10 pages, 2010.

[4] A. L. Burnett, "Nitric oxide-based therapy for erectile disorders," Drug Discovery Today: Therapeutic Strategies, vol. 2, no. 1, pp. 25-30, 2005.

[5] N. Toda, K. Ayajiki, and T. Okamura, "Nitric oxide and penile erectile function," Pharmacology and Therapeutics, vol. 106, no. 2, pp. 233-266, 2005.

[6] J. Manosroi, A. Manosroi, and U. Rungruangsri, "Translation of lanna medicinal-plant recipes for research and development of modern pharmaceuticals and the understanding of the Lanna Thai cultures/histories," Chiang Mai University Journal of Natural Sciences, vol. 5, no. 3, pp. 437-442, 2016.

[7] Abcam. PDE activity assay kit (colorimetric): instructions for use. Version 1. Last updated: 17 May 2013.

[8] L. C. Green, D. A. Wagner, J. Glogowski, P. L. Skipper, J. S. Wishnok, and S. R. Tannenbaum, "Analysis of nitrate, nitrite, and $[15 \mathrm{~N}]$ nitrate in biological fluids," Analytical Biochemistry, vol. 126, no. 1, pp. 131-138, 1982.

[9] P. A. Egwaikhide and C. E. Gimba, "Analysis of the phytochemical content and anti-microbial activity of Plectranthus glandulosis whole plant," Middle-East Journal of Scientific Research, vol. 2, no. 3-4, pp. 135-138, 2007.

[10] A. Manosroi, H. Akazawa, K. Pattamapun et al., "Potent antiproliferative effects against oral and cervical cancers of Thai medicinal plants selected from the Thai/Lanna medicinal plant recipe database "mANOSROI III"," Pharmaceutical Biology, vol. 53, no. 7, pp. 1075-1081, 2015.

[11] Organization for Economic Co-operation and Development. OECD guideline for testing of chemicals: acute oral toxicity up-and-down procedure (OECD guideline no. 425). Adopted on 17 th December 2001.

[12] M. Aslam and A. A. Sial, "Effect of hydroalcoholic extract of cydonia oblonga miller (Quince) on sexual behaviour of wistar rats," Advances in Pharmacological Sciences, vol. 2014, Article ID 282698, 6 pages, 2014.

[13] W. C. Young, J. L. Boling, and R. J. Blandau, "The vaginal smear picture, sexual receptivity and time of ovulation in the albino rat," The Anatomical Record, vol. 80, no. 1, pp. 37-45, 1941.

[14] Y. M. Toyin and N. Q. Olaide, "Effects of aqueous extract of Cnestis ferruginea (Vahl ex De Cantolle) root on paroxetineinduced sexual dysfunction in male rats," Asian Pacific Journal of Reproduction, vol. 1, no. 2, pp. 111-116, 2012.

[15] A. Ågmo, "Male rat sexual behavior," Brain Research Protocols, vol. 1, no. 2, pp. 203-209, 1997.

[16] W. Yasothara and M. Phukphon, "Effect of ethanolic seed extract of Nelumbonucifera on male rat sexual behavior," KKU Research Journal, vol. 19, pp. 156-61, 2014.

[17] Pfizer Labs. 2007. Viagra ${ }^{\circledR}$ (sildenafil citrate) tablets. LAB-02206.0 (October 2007). Available from: http://www.accessdata.fda .gov/drugsatfda_docs/label/2007/020895s027lbl.pdf.

[18] J. D. Corbin, "Mechanisms of action of PDE5 inhibition in erectile dysfunction," International Journal of Impotence Research, vol. 16, supplement 1, pp. S4-S7, 2004.

[19] F. Orallo, M. Camiña, E. Álvarez, H. Basaran, and C. Lugnier, "Implication of cyclic nucleotide phosphodiesterase inhibition in the vasorelaxant activity of the citrus-fruits flavonoid $( \pm)$ naringenin," Planta Medica, vol. 71, no. 2, pp. 99-107, 2005. 
[20] G. G. Peter and A. B. Joseph, "Inhibition and Stimulation of photoreceptor tor Phosphodiesterases by," Dipyridamole and $M$ $B$, vol. 22, p. 948, 1988.

[21] P. Temkitthawon, J. Viyoch, N. Limpeanchob et al., "Screening for phosphodiesterase inhibitory activity of Thai medicinal plants," Journal of Ethnopharmacology, vol. 119, no. 2, pp. 214217, 2008.

[22] P. Temkitthawon, T. R. Hinds, J. A. Beavo et al., "Kaempferia parviflora, a plant used in traditional medicine to enhance sexual performance contains large amounts of low affinity PDE5 inhibitors," Journal of Ethnopharmacology, vol. 137, no. 3, pp. 1437-1441, 2011.

[23] P. Saraithong, S. Saenphet, and K. Saenphet, "Safety evaluation of ethanol extracts from Boesenbergia rotunda (L.) Mansf. in male rats," Trends Research in Science and Technology, vol. 2, no. 1, pp. 19-22, 2010.

[24] H. Li and U. Forstermann, "Nitric oxide in the pathogenesis of vascular disease," The Journal of Pathology, vol. 190, pp. 244-254, 2000.

[25] N. A. Yusuf, M. Suffian, M. Annuar, and N. Khalid, "Existence of bioactive flavonoids in rhizomes and plant cell cultures of Boesenbergia rotunda (L.) Mansf. Kulturpfl," Australian Journal of Crop Science, vol. 7, no. 6, pp. 730-734, 2013.

[26] S. Luanchoy, S. Tiangkul, Y. Wongkrajang, R. Temsiririrkkul, P. Peungvicha, and S. Nakornchai, "Antioxidant activity of a Thai traditional formula for longevity," Mahidol University Journal of Pharmaceutical Sciences, vol. 41, no. 3, pp. 1-5, 2014.

[27] M. Appeldoorn, D. Venema, T. Peters et al., "Some phenolic compounds increase the nitric oxide level in endothelial cells in vitro," Journal of Agricultural and Food Chemistry, vol. 57, no. 17, pp. 7693-7699, 2009.

[28] X. Wang, R. Zhang, L. Gu et al., "Cell-based screening identifies the active ingredients from Traditional Chinese Medicine formula Shixiao San as the inhibitors of atherosclerotic endothelial dysfunction," PLoS ONE, vol. 10, no. 2, Article ID e0116601, 2015.

[29] T. Wallerath, D. Poleo, H. Li, and U. Förstermann, "Red wine increases the expression of human endothelial nitric oxide synthase: a mechanism that may contribute to its beneficial cardiovascular effects," Journal of the American College of Cardiology, vol. 41, no. 3, pp. 471-478, 2003.

[30] B. C. Tan, S. K. Tan, S. M. Wong, N. Ata, N. A. Rahman, and N. Khalid, "Distribution of flavonoids and cyclohexenyl chalcone derivatives in conventional propagated and in vitro-derived field-grown Boesenbergia rotunda (L.) Mansf," Evidence-based Complementary and Alternative Medicine, vol. 2015, Article ID 451870, 7 pages, 2015.

[31] W.-C. Ko, C.-M. Shih, Y.-H. Lai, J.-H. Chen, and H.-L. Huang, "Inhibitory effects of flavonoids on phosphodiesterase isozymes from guinea pig and their structure-activity relationships," Biochemical Pharmacology, vol. 68, no. 10, pp. 2087-2094, 2004.

[32] Y. Mimaki, Y. Sashida, O. Nakamura, T. Nikaido, and T. Ohmoto, "Steroidal saponins from the bulbs of Lilium regale and L. henryi," Phytochemistry, vol. 33, no. 3, pp. 675-682, 1993.

[33] M. Kuroda, Y. Mimaki, A. Kameyama, Y. Sashida, and T. Nikaido, "Steroidal saponins from Allium chinense and their inhibitory activities on cyclic AMP phosphodiesterase and $\mathrm{Na}^{+}$ $\mathrm{K}^{+}$ATPase," Phytochemistry, vol. 40, no. 4, pp. 1071-1076, 1995.

[34] L. Tian, Z.-C. Xin, W.-J. Liu et al., "Effects of icariin on the erectile function and expression of nitrogen oxide synthase isoforms in corpus cavernosum of arterigenic erectile dysfunction rat model," Zhonghua yi xue za zhi, vol. 84, no. 11, pp. 954-957, 2004.
[35] R. Upadhyaya, R. P. Pandey, V. Sharma, and A. K. Verma, "Assessment of the multifaceted immunomodulatory potential of the aqueous extract of Tinospora cordifolia," Research Journal of Chemical Sciences, vol. 1, no. 6, p. 71, 2011.

[36] S. Reagan-Shaw, M. Nihal, and N. Ahmad, "Dose translation from animal to human studies revisited," The FASEB Journal, vol. 22, no. 3, pp. 659-661, 2008. 




The Scientific World Journal
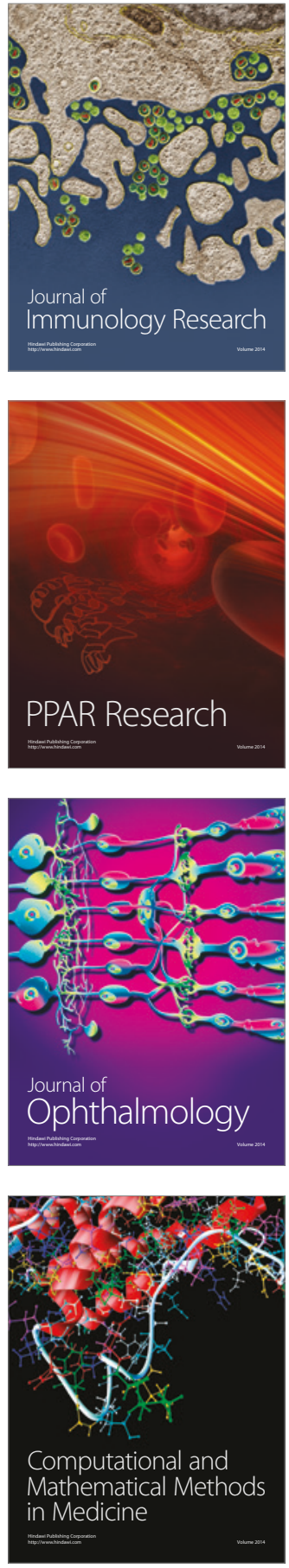

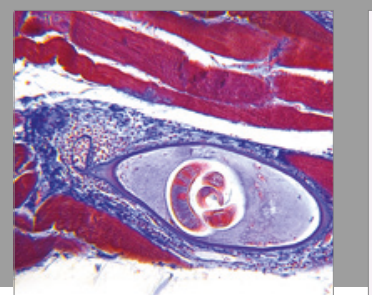

Gastroenterology Research and Practice
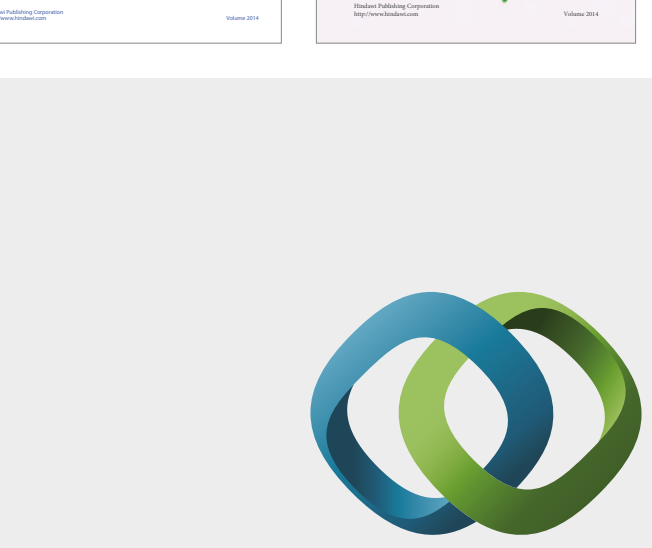

\section{Hindawi}

Submit your manuscripts at

https://www.hindawi.com
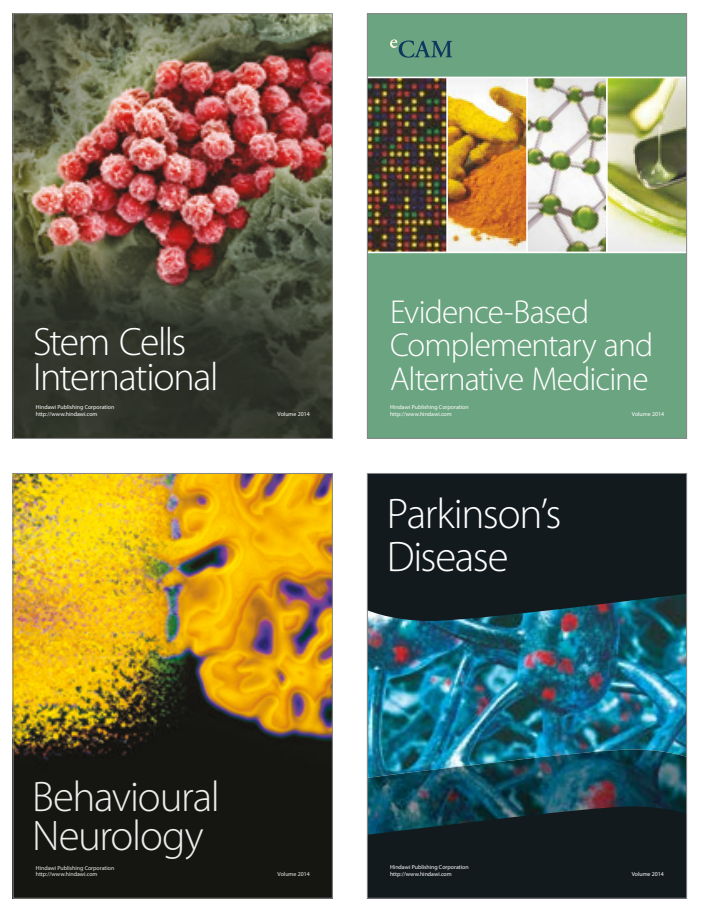
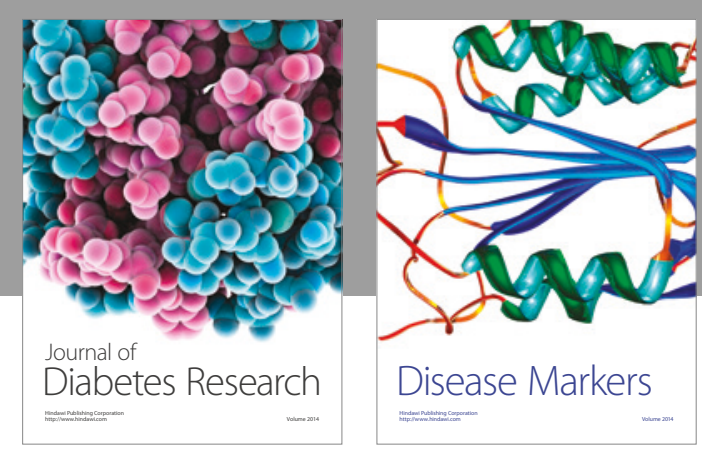

Disease Markers
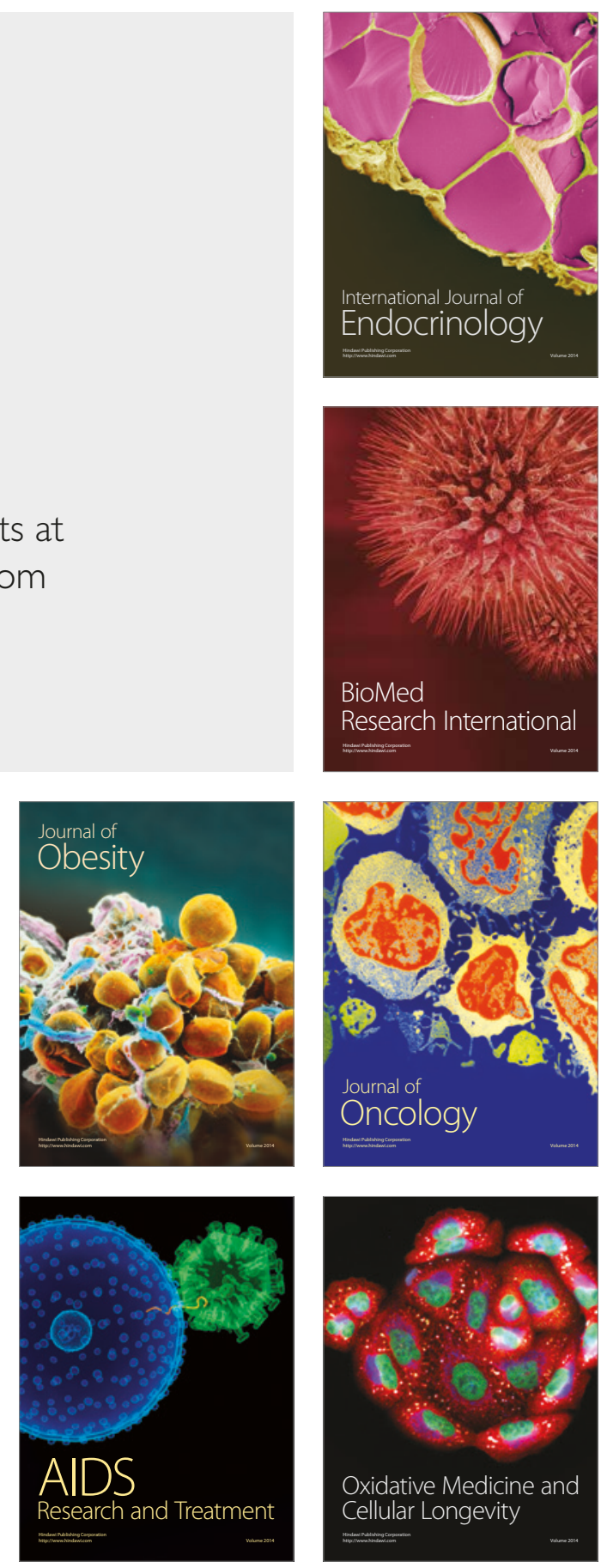